\title{
Studies of the rate homology between 16S rRNA gene in the uncultured Paenibacillus species clone: T-168 and other 16S rRNA gene in the Paenibacillus species
}

\author{
Abolhasan Rezaei \\ Department of Basic Science, Tonekabon Branch, Islamic Azad University, \\ Tonekabon, Iran. \\ E.mail: a.rezaei@tonekaboniau.ac.ir.
}

\begin{abstract}
The uncultured Paenibacillus species clone: T-168 was isolated from muscle tissue of salmo trutta caspius (fish species) for studies of their 16S rRNA gene. A one pair of 16S rRNA gene was designed by BLAST and DNAMAN computer program. After amplifying of RNA gene, were sequenced and deposited GenBank, accession number, AB828175.1. 16S rRNA gene of uncultured Paenibacillus clone: T-168 were aligned between some species of bacteria specially Paenibacilus. The results showed that there was homology between 16S rRNA gene of uncultured Paenibacillus clone: T-168 and 16S rRNA gene in other species of bacteria.
\end{abstract}

Keywords: 16S rRNA gene of uncultured Paenibacillus clone: T-168, Bacteria, sequencing.

\section{INTRODUCTION}

Paenibacilli have been isolated from a variety of sources including soil, water, the plant rhizosphere, food, and diseased insect larvae, but not from clinical specimens (Daane et al. 2002). This species were applied for industrial and agricultural development. Some paenibacilus species were used for nitrogen fixation in which atmospheric nitrogen including 45 recognized Paenibacillus species (NCBI homepage, November 2003). Also their ability to produce phytohormones, suppress phytopathogens through antagonistic functions and solubilize organic phosphate (Mavingui and Heulin, 1994; Lebuhn et al. 1997; Pires and Seldin, 1997), they can also be of industrial importance due to the production of antibiotics, chitinases, amylases and proteases (Mavingui and Heulin, 1994; von der Weid et al. 2003). Were studied on the phylogenetic of Paenibacillus species for finding rate of homology between species and subspecies of the Paenibacillus. As following that, studied on the $16 \mathrm{~S}$ rRNA sequences, were used studies on phylogenetic of the new genus of Paenibacilus species. (Ash et al. 1993; Heyndrickx et al. 1996; Coelho et al. 2003; Silva et al. 2003; Daane et al. 2002; Chung et al. 2000; Stackebrandt et al. 1997). For Paenibacilus species were found 10 copies of the 16S rRNA gene in their genomics (Heyndrickx et al. 1996; Berge et al. 2002). 16S rRNA gene also were analyzed in Bacterial genomics (Woese et al., 1990) and analysis of bacterial diversity (Bosshard et al. 2003; Fox et al.1980). the similarity of some members of the genus Paenibacillus was observed $<92 \%$, this similarity is very important between and whiten species of Paenibacillus. There are some reports about uncultured Paenibacillus species T-160 in GenBank (accession number, HQ616297.1), Paenibacillus sp. C-168 16S rRNA gene, accession number, Y16129.1, Paenibacillus sp. T-168 16S rRNA gene, accession number, Y16128. They found that a $1400 \mathrm{bp}$ to 1500 full length sequencing that revealed a high similarity with uncultured 
Paenibacillus species and also 16S rRNA gene in bacterial. In this study, we sequenced and deposited a fragment $677 \mathrm{bp}$. of 16S rRNA gene in GenBank, accession number; AB828175.1. Therefore, we aimed analyses of the rate relationship between and within uncultured Paenibacillus species, because there was some publications deal with intraspecific polymorphisms in 16S rRNA genes (Bricker, 2000; Cilia et al. 1996; Liefting et al. 1996; Martolnez- Murcia et al. 1999; Ninet et al. 1996; Nubel et al. 1996; Pettersson et al. 1998; Reischl et al. 1998). Hence, we decided to investigate this strain by molecular techniques.

\section{MATERIALS AND METHODS}

Bacterial isolation and phenotypic characterization: Uncultured Paenibacillus were isolated from muscle tissue of Salmo trutta caspius (fish species). The morphology of the bacteria was examined using visual investigation and a light microscope. Motility tests were performed using the hanging-drop technique and motility medium plates ( $1 \%$ nutrient broth, 5.3 gelatin, $0.3 \%$ agar, $0.1 \% \mathrm{KNO}, \mathrm{pH}$ 7.2) that were incubated overnight at $30^{\circ} \mathrm{C}$. Anaerobic growth was determined by incubating LA plates overnight at $30^{\circ} \mathrm{C}$ in Incubator. Optimum growth temperatures were determined in LB by shaking at $160 \mathrm{rpm}$ and spectrophotometric reading.

DNA isolation: Total cellular DNA was isolated from bacterial colony following described by Sambrook et al., (1998). Briefly, samples was digested in a digestion buffer, containing; (100 mM NaCl, $10 \mathrm{mM}$ Tris pH 8.0, 25 rnM EDTA pH 8.0, 0.5\% sodium dodecyl sulphate (SDS), $0.1 \mathrm{mg} / \mathrm{ml}$ proteinase K). Samples were then extracted with an equal volume of phenol-chloroform-isoamyl alcohol $(24: 25: 1)$.Vortexed $10 \mathrm{~s}$ then centrifuged at $3000 \times \mathrm{g}$ for $5 \mathrm{~min}$ at room temperature. DNA was precipitated overnight at $4^{\circ} \mathrm{C}$ with $1 / 2 \mathrm{Vol} 7.5 \mathrm{M}$ ammonium acetate and 2 vol $100 \%$ ethanol. Then DNA solved in TE buffer (10 rnM Tris-CI, 1mM EDTA) pH 8.0. Samples were stored at $-20^{\circ} \mathrm{C}$ until analysis. Then the DNA genomics amplified $16 \mathrm{~S}$ rRNA gene gene was separated by $1.5 \%$ agarose gel electrophoresis. After electrophoresis, the DNA full length was visualized ethidium bromide and then was taken photos by gel DOC Bio RAD Company.

Designing of primers: Primers designed to specifically amplify the 16s rRNA gene based on conserved sequences from regions identified by the alignment of all the available sequences data from several the Paenibacillus species. These primers can amplified from first to end of 16s rRNA gene. These primers including:

Forward Primer 5' CACCTCCCTTACACCGAGAA 3'

Reverse Primer 5' GCCGAGTTCCTTCTCTTCCT 3'

The PCR programs: The PCR reaction used 10 microgram PCR reactions contained: $2 \mu 1$ template DNA, $2 \mu \mathrm{l}$ forward primer $(100 \mathrm{ng} / \mu \mathrm{l}), 2 \mu \mathrm{l}$ reverse primer (100 ng/ $\mu \mathrm{l}), 2 \mu \mathrm{dNTP}$ mix (2.5mM each), $5 \mu 1$ 10X ChromTaq Assay buffer, $0.5 \mu \mathrm{l}$ ChromTaq enzyme $(3 \mathrm{U} / \mu \mathrm{l})$, Water $37.5 \mu \mathrm{l}$, in a total volume, $50 \mu 1.95^{\circ}$ of $10 \mathrm{~min}$, 30 cycles of $95^{\circ} \mathrm{C} 60 \mathrm{Sec} ., 52-60^{\circ} \mathrm{C} 55 \mathrm{Sec}$, and $72^{\circ} \mathrm{C} 1.5 \mathrm{~min}$. Two to ten $\mu 1$ of each PCR reaction were run on $1.5 \%$ agarose gels in TAE buffer containing ethidium bromide. One $\mu 1500 \mathrm{bp}$, DNA ladder (Gibco-BRL) was used as a size standard. Then the PCR products after purification by the Chromous kit purification were sent to the Chromous Geni Company-India for doing sequence.

Sequencing of 16S rRNA gene in the Uncultured Paenibacillus species clone T168: For sequencing of $16 \mathrm{~S}$ rRNA gene we designed one set of primer that process of the sequencing including: 
PCR Purification: Amplified PCR product was purified using QIAquick PCR Purification Kit Protocol:

A. Added 5 volumes of Buffer PB to one volume of the PCR sample and mixed. B. Placed a QIAquick spin column in a provided $2 \mathrm{ml}$ collection tube. C. Centrifuged at $8000 \mathrm{rpm}$ for 30-60 s. D. Discarded flow-through. Placed the QIAquick column back into the same tube. E. Washed with $0.75 \mathrm{ml}$ Buffer PE to the QIAquick column and centrifuged for 30-60 s. F. Discarded the flow-through and placed the QIAquick column back in the same tube. G. Centrifuged the column for an additional $1 \mathrm{~min}$ at maximum speed. H. Placed QIAquick column in a clean $1.5 \mathrm{ml}$ micro centrifuge tube. K. To elute PCR product, added $40 \mu \mathrm{l}$ of B H2O to the center of the QIAquick membrane and centrifuged the column for $1 \mathrm{~min}$.

\section{Sequencing of Amplified 16S rRNA gene:}

Sequencing was performed along with the Forward and reverse primers in ABI 3730XL high throughput sequencer machine. Forward and reverse sequences were assembled and edited.

\section{Sequence data analyzes}

Sequence data were analyzed mostly by BLAST (NCBI Network system) and DNAMAN computer program genetics.

\section{RESULTS}

DNA extraction: In this study, after acquired the colony of bacteria, we extracted total DNA genomic from uncultured Paenibacillus T-168 (Fig.1). For amplification of 16S rRNA gene were designed one pair of primer from some species of Paenibacillus that reported in GenBank.

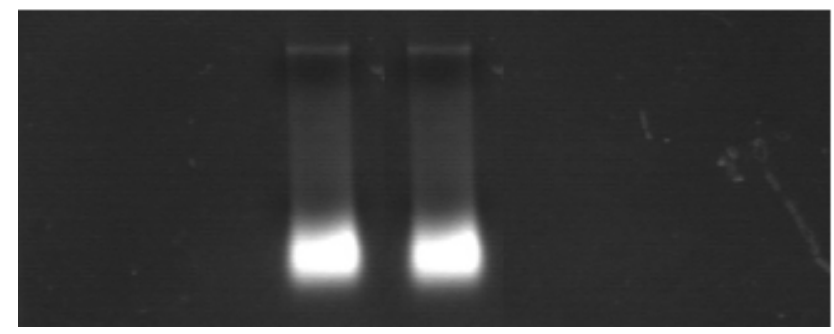

Fig. 1: Total genomic DNA of Uncultured Paenibacillus sp. clone: T-168.

We analysed by NCBI Network system and DNAMAN program computer. We selected one pair universal primer for amplification part of the 16S rRNA gene. These primers produced around $670 \mathrm{bp}$. PCR product that shown in Fig. 2.

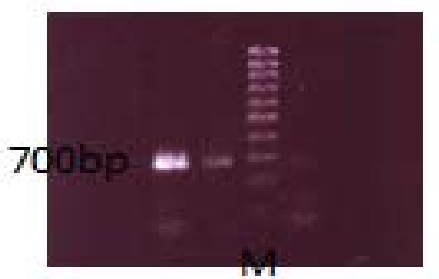

Fig. 2: PCR product of partial sequence of $16 \mathrm{~S}$ rRNA gene in Uncultured Paenibacillus sp. clone: T168. M: Size marker 1000bp.

\section{Identification and characterization of $16 \mathrm{~S}$ ribosomal RNA gene:}

The PCR amplification generated approximately a 700bp. The nucleotide sequences as well as deposited in (GenBank, accession number, AB828175.1. Sequence of 16S rRNA gene in Uncultured Paenibacillus sp. clone: T-168 were 
aligned with 16S rRNA genes in Paenibacillus species T-168 16S, accession no. Y16128.1, in BLAST. The homology between both sequences was high however this homology was partial sequences of them (Figure 3and4). Sequence of acquired were analysed with some 16S rRNA genes including: Paenibacillus sp. T-168, accession no. Y16128.1. Paenibacillus lentimorbus strain ATCC 14707, accession no. NR_040889.1. Uncultured Paenibacillus sp. clone T- T0275, accession no. HQ616297.1. Paenibacillus lentimorbus, accession no. AB110988. Paenibacillus sp. C-168, accession no.Y16129.1. Paenibacillus sp. accession no. EU876668.1. Uncultured Paenibacillus sp. clone P4S-226, accession no. GQ329306.1. Paenibacillus sp. accession no. Y11583. Uncultured paenibacillus sp. clone P8S-359, accession no. GQ329445 (Fig. 5) and these sequences again were analyzed with DNAMAN computer program (Fig. 6). The results showed that, there was homology between sequences, approximately $82.1 \%$.

\begin{tabular}{|c|c|}
\hline AB828175.1 & $\begin{array}{l}\text { GGTGGGGATGACGTCAAATCATCATGCCCCTTATGACCTGGGCTACACACGTACTACAAT } \\
\qquad \begin{array}{l}1213 \\
\text { GGTGGGGAAGACCTCAAATCAAAATACCCCTTTTGACTTGGGCTGCACACTTCTTACAGT }\end{array}\end{array}$ \\
\hline Y16128.1 & 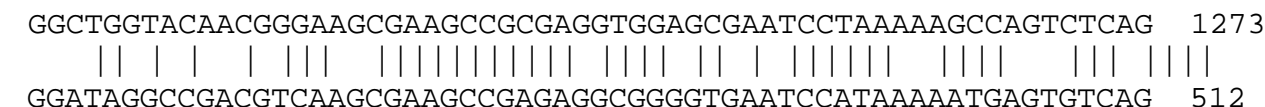 \\
\hline $\begin{array}{l}\text { AB828175.1 } \\
\text { Y16128.1 }\end{array}$ & 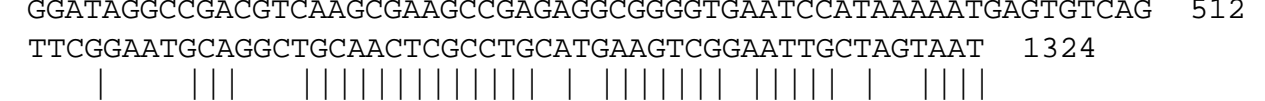 \\
\hline
\end{tabular}

Fig. 3: The sequences of $16 \mathrm{~S}$ rRNA gene in Uncultured Paenibacillus species clone: T-168. Accession no. AB828175.1 and, Paenibacillus species T-168 16S rRNA gene, accession no. Y16128.1, were analysed in Blast NCBI Network system. The results showed that there were homology between them.

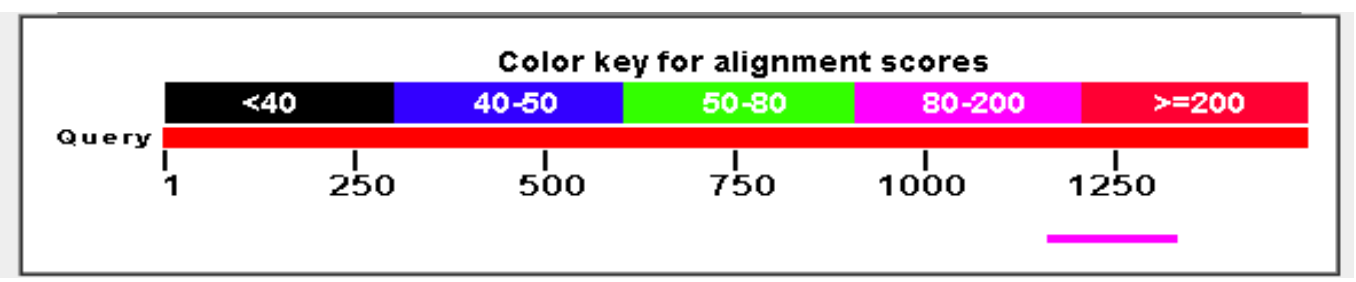

Fig. 4: Structure of graphical 16S rRNA gene in Uncultured Paenibacillus sp. clone: T-168. AB828175.1 (down line color) and, Paenibacillus species. T-168 16S rRNA gene, accession no. Y16128.1(above line color). Positions of colors indicated that there were homology only space of 80 to 200 nucleotides between them.

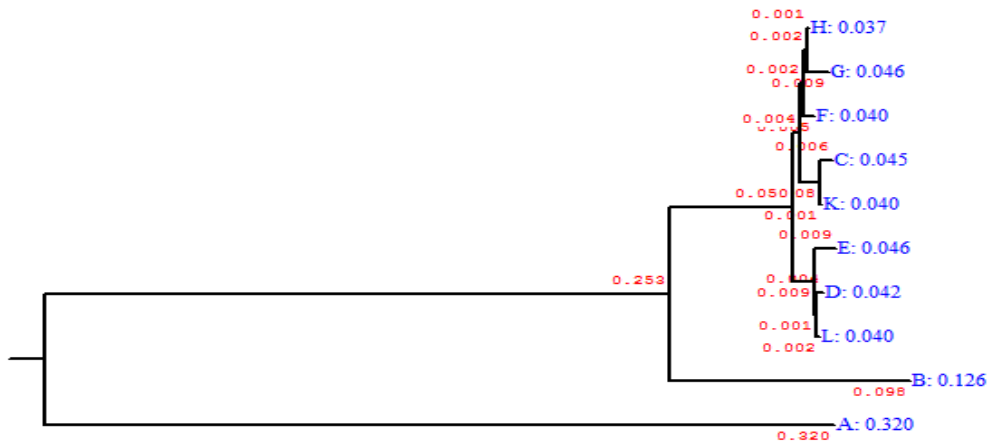

Fig. 5: Dendrogram analysis of 16S rRNA gene in Uncultured Paenibacillus sp. clone: T-168. AB828175.1(A). Paenibacillus sp. T-168, accession no. Y16128.1(B). Paenibacillus lentimorbus strain ATCC 14707, accession no. NR_040889.1(C). Uncultured Paenibacillus sp. clone T- T0275, accession no. HQ616297.1(D). Paenibacillus lentimorbus, accession no. AB110988(E). Paenibacillus sp. C-168, accession no.Y16129.1 (F). Paenibacillus sp. accession no. EU876668.1(G), and, Uncultured Paenibacillus sp. clone P4s-226, accession no. GQ329306.1 (H). Paenibacillus sp. accession no. Y11583(K). Uncultured paenibacillus sp. clone P8s-359, accession no. GQ329445 (L). Dendrogram indicated that there were homology between them but it is low. 


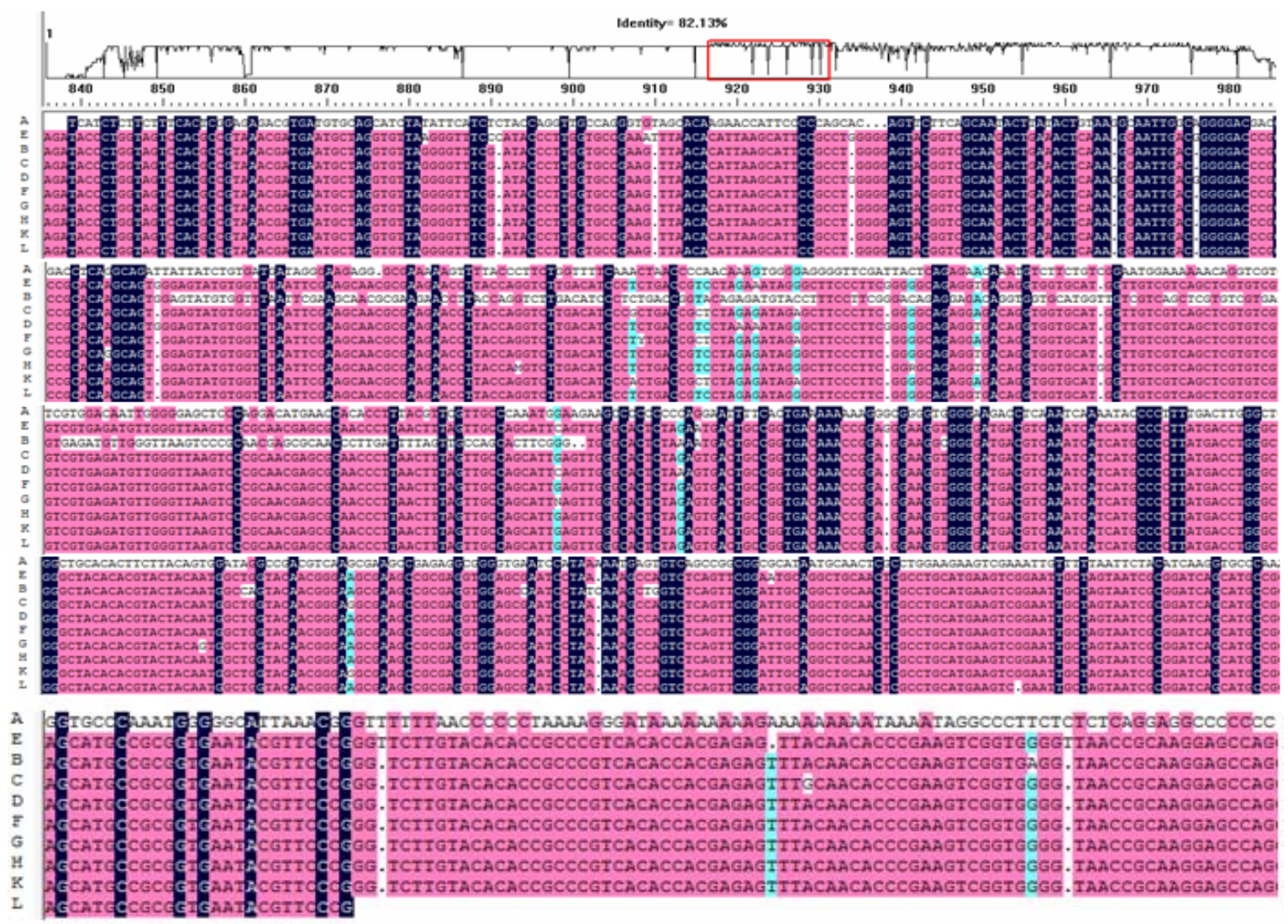

Fig. 6: The sequences of 16S rRNA gene in Uncultured Paenibacillus sp. clone: T-168. AB828175.1 (A), 16S rRNA gene in Uncultured Paenibacillus sp. clone: T-168. AB828175.1 (A). Paenibacillus sp. T-168, accession no. Y16128.1 (B). Paenibacillus lentimorbus strain ATCC 14707, accession no. NR_040889.1(C). Uncultured Paenibacillus sp. clone T- T0275, accession no. HQ616297.1(D). Paenibacillus lentimorbus, accession no. AB110988 (E). Paenibacillus sp. C-168, accession no.Y16129.1 (F). Paenibacillus sp. accession no. EU876668.1(G), and, Uncultured Paenibacillus sp. clone P4s-226, accession no. GQ329306.1 (H). Paenibacillus sp. accession no. Y11583(K). Uncultured paenibacillus sp. clone P8s-359 16S rRNA gene, accession no. GQ329445 (L). Positions of colors indicated that there were homology only space of 80 to 200 nucleotides between them.

\section{DISCUSSION}

This study we isolated uncultured Paenibacillus species from muscle of fishes. Uncultured Paenibacillus live in environment such as, soil, water, vegetable matter, forage and insect larvae, human, as well as clinical samples ( Lal and Tabacchioni, 2009; McSpadden Gardener, 2004; Montes et al. 2004; Ouyang, 2008). Still, today, there is not any report that fish species is host of uncultured Paenibacillus species. Therefore, this is a novel discovery regarding different bacteria species. We cultured Paenibacillus in muscle fishes after screening bacteria; we isolated DNA genomic and finally had done sequencing of $16 \mathrm{~S}$ rRNA gene. There were many studies about functional of $16 \mathrm{~S}$ rRNA gene in uncultured Paenibacillus in phylum of Bacteria (Cloud et al. 2002; Tortoli et al. 2001; Hall et al. 2001; Stackebrandt et al. 2002).

They also found a good homology between bacterial 16S rRNA gene and Paenibaclus species (reflected to NCBI Network system, accession number of 16 SrRNA gene in bacterial and specially Paenibacilus species) but our results showed that the rate of homology was medium, these results suggests that three theory including:1) may be this species (Uncultured Paenibacillus sp, clone T-168) a novel 
bacteria, that can be existence by genetic mutation, 2) still we didn't sequence full length of 16S rRNA gene, therefore, after getting full length may be reduce the genetic variation and has been high homology between uncultured Paenibacillus sp, clone T-168 and other same species. 3) may be only variation was there on the $16 \mathrm{~S}$ rRNA gene and the rate of homology after getting sequence from other nuclear genomics may be increased. However, the third theory is impossible because there is more research denote that $16 \mathrm{~S}$ rRNA gene usually between organisms has been high homology, therefore, in the bacterial genomics also, 16S rRNA gene has high homology between species, and there are more reports about phylum of bacterial that used 16S rRNA gene. Bosshard et al. (2003), who reported that $14 \%$ of all aerobic gram-positive rods isolated in their clinical microbiology laboratory would require 16S rRNA gene sequence-based identification (3). These data indicate that molecular identification of unidentifiable bacterial isolates offers an opportunity for the description of new bacterial species encountered in clinical microbiology laboratories.

The fact that the commercially available $16 \mathrm{~S}$ rRNA gene sequence-based identification kits have been favourably evaluated (Coelho, 2003; Tang, 2000; Woese et al. 1990) indicates that an exponential increase in the use of the technique can be expected within the next few years. Indeed, 16S rRNA gene sequencing offers an unprecedented tool for the description of new bacterial species. In figure 3-6, $16 \mathrm{~S}$ rRNA gene in uncultured Paenibacillus species, clone T-168 with 16S rRNA gene in Paenibacillus sp. T-168. were analysed by Blast, NCBI Network system. Results showed that the homology between both were low, 16S rRNA gene in Paenibacillus sp. T-168 has around $1250 \mathrm{bp}$. that approximately had homology $200 \mathrm{bp}$ of 16S rRNA gene in uncultured Paenibacillus species clone T-168 with 16S rRNA gene in Paenibacillus species T-168, this annotated only the part of end of both sequences had high homology and first to medium of sequences there was not any homology. However in figure 5, 16S rRNA gene in uncultured Paenibacillus species clone T-168 with 16S rRNA gene of bacterial and uncultured Paenibacillus species by DNAMAN computer program were aligned, the results showed that there were homology between sequences of $16 \mathrm{~S}$ rRNA gene in between and within of species bacteria(approximately $82 \%$ ). As above results, we concluded that should be sequence full length of $16 \mathrm{~S}$ rRNA gene and use more genes for studies of phylogenetic in bacteria.

\section{ACKNOWLEDGMENTS}

This work was financially supported by the Research Council of Islamic Azad University Tonekabon Branch, Iran.

\section{REFERENCES}

Ash, C., Priest, F. G., Collins, D. (1993). Molecular identification of rRNA group 3 bacilli (Ash, Farrow, Wallbanks and Collins) using a PCR probe test. Proposal for the creation of a new genus Paenibacillus. Anton. Van. Leeuw. 64:253-260.

Berge, O., Guinebretiere, M.H., Achouak, W., Normand, P. Heulin, T. (2002). Paenibacillus graminis sp. nov. and Paenibacillus odorifer sp. nov., isolated from plant roots, soil and food. Inte J Sys Evol Micr., 52: 607-616.

Bricker, B. J. (2000). Characterization of the three ribosomal RNA operons $r r n A, r r n B$, and $r r n C$, from Brucella melitensis. Gen. 255: 117-126.

Bosshard, P. P., S. Abels, R. Zbinden, E. C. Bottger., Altwegg, M. (2003). Ribosomal DNA sequencing for identification of aerobic gram-positive rods in the clinical laboratory (an 18 month evaluation). J. Clin. Microbiol., 41: 4134-4140. 
Chung, Y. R., Kim, C. H., Hwang, I., Chun, J. (2000). Paenibacillus koreensis sp. nov., a new species that produces an iturin-like antifungal compound. Int. J. Syst. Evol. Microbiol. 50:1495-1500.

Cilia, V., Lafay, B., Christen, R. (1996). Sequence heterogeneities among 16S ribosomal RNA sequences, and their effect on phylogenetic analyses at the species level. Mol. Biol. Evol., 13: 451-461.

Cloud, J. L., Neal, H., Rosenberry, R., Turenne, C.Y., Jama, M., Hillyard, D.R., Carroll, K.C., (2002). Identification of Mycobacterium spp. by using a commercial 16S ribosomal DNA sequencing kit and additional sequencing libraries. J. Clin. Microbiol., 40: 400-406.

Coelho, M.R.R., von der Weid, I., Zahner, V., Seldin, L. (2003). Characterization of nitrogen-fixing Paenibacillus species by polymerase chain reaction-restriction fragment length polymorphism analysis of part of genes encoding $16 \mathrm{~S}$ rRNA and 23S rRNA and by multilocus enzyme electrophoresis. FEMS. Micr. Let., 222: 243-250.

Daane, L. L., Harjono, I., Barns, S. M., Launen, L. A., Palleroni, N. J. Haaggblom, M. M. (2002). PAH-degradation by Paenibacillus spp. and description of Paenibacillus naphthalenovorans sp. nov., a naphthalene-degrading bacterium from the rhizosphere of salt marsh plants. Int. J. Syst. Evol. Microbiol., 52: 131-139.

Fox, G. E., Stackebrandt, E., Hespell, R. B. and 16 other authors. (1980). The phylogeny of prokaryotes. Sci., 209: 457-463.

Hall, V., Talbot, P. R., Stubbs, S. L., Duerden, B. I. (2001). Identification of clinical isolates of actinomyces species by amplified $16 \mathrm{~S}$ ribosomal DNA restriction analysis. J. Clin. Microbiol., 39:3555-3562.

Heyndrickx, M., Vandemeulebroecke, K., Scheldeman, P., Kersters, K., De Vos, P., Logan, N.A., Aziz, A.M. and Berkeley, R.C.W. (1996). A polyphasic reassessment of the genus Paenibacillus, reclassification of Bacillus lautus (Nakamura 1984) as Paenibacillus lautus comb. nov. and Bacillus peoriae (Montefusco et al. 1993) as Paenibacillus peoriae comb. nov., and emended description of P. lautus and P. peoriae. Inte. J. Sys. Micr. 46: 988-1003.

Sambrook, J., Fritsch, E. F., Maniatis, T. (1989). Molecular cloning: a laboratory manual, $2^{\text {nd }}$ edition. Cold Spring Harbor Laboratory Press, Cold Spring Harbor.

Stackebrandt, E., Sproer, C., Rainey, F. A., Burghardt, J., Pauker, O., Hippe. H. (1997). Phylogenetic analysis of the genus Desulfotomaculum: evidence for the misclassification of Desulfotomaculum guttoideum and description of Desulfotomaculum orientis as Desulfosporosinus orientis gen. nov., comb. nov. Int. J. Syst. Bact., 47:1134-1139.

Tang, Y. W., Von Graevenitz, A., Waddington, M. G., Hopkins, M. K., Smith, D. H., Li, H., Kolbert, C. P., Montgomery, S. O., Persing, D. H. (2000). Identification of coryneform bacterial isolates by ribosomal DNA sequence analysis. J. Clin. Microbiol., 38:1676-1678.

Tortoli, E., Bartoloni, A., Bottger, E. C. Emler, S., Garzelli, C., Magliano, E., Mantella, A., Rastogi, N., Rindi, L., Scarparo, C., Urbano, P. (2001). Burden of unidentifiable mycobacteria in a reference laboratory. J. Clin. Microbiol., 39: 4058-4065.

Lal, S., Tabacchioni, S. (2009). Ecology and biotechnological potential of Paenibacillus polymyxa: a minireview. Ind. J. Microbiol., 49: 2-10.

Liefting, L. W., Andersen, M. T., Beever, R. E., Gardner, R. C., Forster, R. L. (1996). Sequence heterogeneity in the two 16S rRNA genes of Phormium yellow leaf phytoplasma. Appl. Environ. Microbiol., 62: 3133-3139.

Lebuhn, M., Heulin, T., Hartmann, A. (1997). Production of auxin and other indolic and phenolic compounds by Paenibacillus polymyxa strains isolated from different proximity to plant roots. FEMS Micr. Eco., 22: 325-334. 
Mavingui, P., Heulin, T. (1994). In vitro chitinase antifungal activity of a soil, rhizosphere and rhizoplane populations of Bacillus polymyxa. Soil. Bio. Bio., 26: 801-803.

Martinez-Murcia, A. J., Antin, A. I., Rodriguez-Valera, F. (1999). Patterns of sequence variation in two regions of the 16S rRNA multigene family of Escherichia coli. Int. J. Syst. Bacterio., 49: 601-610.

McSpadden Gardener, B.B. (2004). Ecology of Bacillus and Paenibacillus spp. in Agricultural Systems. Phy., 94:1252-1258.

Montes, M.J., Mercade, E., Bozal, N., Guinea, J. (2004). Paenibacillus antarcticus sp. nov., a novel psychrotolerant organism from the Antarctic environment. Int. J. Syst. Evol. Microbiol., 54:1521-1526.

Ninet, B., Monod, M., Emler, S., Pawlowski, J., Metral, C., Rohner, P., Auckenthaler, R., Hirschel, B. (1996). Two different 16S rRNA genes in a mycobacterial strain. J. Clin. Microbiol., 34: 2531-2536.

Nubel, U., Engelen, B., Felske, A., Snaidr, J., Wieshuber, A., Amann, R. I., Ludwig, W., Backhaus, H. (1996). Sequence heterogeneities of genes encoding 16S rRNAs in Paenibacillus polymyxa detected by temperature gradient gel electrophoresis. J. Bacteriol., 178: 5636-5643.

Ouyang, J., Pei Z, Lutwick, L., Dalal, S., Yang, L., Cassai, N., Sandhu K, Hanna B, Wieczorek R.L., Bluth, M., Pincus, M.R. (2008). Case report: Paenibacillus thiaminolyticus: a new cause of human infection, inducing bacteremia in a patient on hemodialysis. Ann. Clin. Lab. Sci., 38:393-400.

Pettersson, B., Bolske, G., Thiaucourt, F., Uhlen, M. and Johansson, K. E. (1998). Molecular evolution of Mycoplasma capricolum subsp. capripneumoniae strains, based on polymorphisms in the 16S rRNA genes. J. Bacteriol., 180: 2350-2358.

Pires, M.N., Seldin, L. (1997). Evaluation of Biology system for identification of strains of Paenibacillus azotofixans. Ant. Van. Leeu., 71: 195-200.

Reischl, U., Feldmann, K., Naumann, L., Gaugler, B. J., Ninet, B., Hirschel, B. \& Emler, S. (1998). 16S rRNA sequence diversity in Mycobacterium celatum strains caused by presence of two different copies of 16S rRNA gene. J. Clin. Microbiol., 36:1761-1764.

Silva, K.R.A., Salles, J.F., Seldin, L and van Elsas, J.D. (2003) Assessment of the diversity of Paenibacillus spp. in the rhizosphere of different maize cultivars in two soils by Paenibacillus-specific PCRDGGE and sequence analysis. J. Micr. Met., 54: 213-231.

Stackebrandt, E., Rainey, F. A. and Ward-Rainey, N. L. (1997). Proposal for a new hierarchic classification system, Actinobacteria classis nov. Int. J. Syst. Bacteriol., 47: 479-491.

Von der Weid, I., Alviano, D.S., Santos, A.L.S., Soares, R.M.A., Alviano, C.S., Seldin, L. (2003). Antimicrobial activity of Paenibacillus peoriae against a broad spectrum of phytopathogenic bacteria and fungi. J. App. Mic., 95:1143-1151.

Woese, C. R., Kandler, O., Wheelis, M. L. (1990). Towards a natural system of organisms: proposal for the domains Archaea, Bacteria, and Eucarya. Proc. Natl. Acad. Sci. USA., 87: 4576-4579. 